\title{
IDEAL SOCIAL ORDER: Why Gandhi, NOT Marx?
}

\author{
Krishna Satapathy \\ Guest Faculty, Dept. of Philosophy \\ S.B.R. Women's College, Berhampur, Odisha. \\ Email: krishnasatathy444@gmail.com
}

\begin{abstract}
It is a question raised in the context of making a choice between the doctrine of Sarvodaya Gandhi and the doctrine of scientific socialism of Marx. Both the epoch-making thinkers have tried to find out ideal social order in order to bring transformation to the social structure of their time. The basic factors on which the doctrine is based are: equality, freedom, statelessness, trusteeship, bread-labor, non-violence, and satyagraha. Looking to its features scholars have considered it to be as good as ethical socialism or ethical absolutism. The ultimate goal of scientific socialism is to set up exploitation free, classless, stateless, and egalitarian socialistic society. In his framework of thought, the basic important factors are bloodshed revolution, class-war, withering away the state, abolition of private property, dictatorship of the proletariat, etc. Gandhi's social order is solely based on certain ethical preoccupations. Karl Marx and Marxist thinkers have glorified violence and preferred the revolutionary method. The Sarvodaya doctrine of Gandhi is an attempt to bridge the gap between theoretical ideas and practice. The emphasis on ethical considerations prompts to choose the Gandhian doctrine in lieu of Marxian.
\end{abstract}

Keywords: Savodaya, Scientific socialism, Ethical socialism, Revolutionary socialism
Reference to this paper should be made as follows:

Received: 16.05 .2020

Approved: 30.06.2020

Krishna Satapathy

IDEAL SOCIAL ORDER:

WHY GANDHI, NOT MARX?

RJPSSs 2020, Vol. XLVI,

No. 1, pp.112-117

Article No.13

Online available at:

http://rjpsss.anubooks.com/ https://doi.org/10.31995/

rjpsss.2020v46i01.13 
RJPSSs, Vol. XLVI No.1, June 2020 ISSN: (P)0048-7325 (e) 2454-7026 Impact Factor 7.821 (SJIF)

https://doi.org/10.31995/rjpsss.2020v46i01.13

\section{Introduction}

It is a question raised in the context of making a choice between the doctrine of Sarvodaya Gandhi and the doctrine of scientific socialism of Marx. (Of course, Marx did not name his doctrine as scientific socialism but the communism of Marx was considered as scientific socialism by Engels.) It is uncontroversial that Gandhi and Marx are two revolutionary thinkers with respect to social reforms. Both of them proposed that state happens to be the engine of violence and anti-state, antiindividualistic measures are necessary for regulating the wealth of the society and equal distribution of the products of the society. A capitalist society suffers from the evils of intensifying the gap between rich and poor. Both the epoch-making thinkers have tried to find out ideal social order in order to bring transformation to the social structure of their time. But it is quite significant that both of them have made completely different approaches to achieve the goal.

It is seen that both of them have been able to imprint their ideas and thoughts in other revolutionary thinkers to take up their ideas further. Vinoba and Jayaprakash were two remarkable followers of Gandhian doctrine of Sarvodaya and Engels, Lenin, and Stalin were staunch followers of Marxian socialism. Hence to find out the answer to the question of the caption it would be a case of choosing between ethical socialism (of Gandhi) and revolutionary socialism (of Marx). Sarvodaya doctrine should be treated as ethical socialism because it envisages an equalitarian, decentralized, and people-oriented social order basically on an ethical foundation. Marxian socialism has been treated as revolutionary socialism because here bloodshed revolution has been suggested to achieve the goal.

Sarvodaya-socialism of Gandhi:

'Sarvodaya', as a concept, is considered as the closest neighbor of the concept of 'socialism'. Gandhi sometimes considered himself to be a socialist but never used the term socialism for his doctrine of Sarvodaya. Looking to its features scholars have considered it to be as good as ethical socialism or ethical absolutism. The basic factors on which the doctrine is based are: equality, freedom, statelessness, trusteeship, bread-labor, non-violence, and satyagraha.

According to Gandhi inequality happens to be the root cause of social evil and exploitation. He wanted equality should be there in every sphere. He has also talked of economic equality to a great extent. For him, the social and economic inequality can be prevented through equality of wages. In Gandhian thought, two concepts, namely equality and freedom have equal importance in order to have an ideal social order. He has emphasized on freedom both from moral and political 
IDEAL SOCIAL ORDER: WHY GANDHI, NOT MARX?

Krishna Satapathy

perspectives. An individual owes some moral responsibility for the society and the state which cannot be possible without freedom. The 'state' represents power centralization. This stands on the way of freedom in many ways. Gandhi has expressed "I look upon an increase in the power of the state with the greatest fear, because although while apparently doing good by minimizing exploitation, it does the greatest harm to mankind by destroying individuality which lies at the root of all progress. The state represents violence in a concentrated and organized form. The individual has a soul, but as the state is a soulless machine, it can never wean from violence to which it owes its very existence. ${ }^{1}$ It is because the state has to function through police, courts, jail, military, violence cannot be avoided Gandhi repudiates the system of state autonomy. Rather he designed the theory of trusteeship to ensure the principle of equality in a Sarvodaya society. Gandhi held the view that property belonged to the society at large and hence it must be used for the welfare of one and all. Thus he visualized a transition from individual ownership to communal ownership. Gandhi wanted that the rich should become the trustee of the society by sharing their surplus wealth with the poor.

Besides trusteeship, Gandhi has also thought of another important means to prevent unjust economic order and social inequality. It is his concept of bread-labor. It emphasizes on the factor that everyone should earn his bread. It is based on the consideration that the needs of the body must be supplied by the body. If someone does not come forward for earning his own bread then he is likely to become a thief. Hence in order to live, man must work. For this idea of bread-labour Gandhi might have been influenced by the Bible and the Geeta. Because the Bible says, 'Earn they bread by the sweat of thy brow' and Geeta also says that he who eats without laboring for it then he is eating food meant for others or the stolen food.

The concept of non-violence is very old in Indian religions and philosophy but Gandhi has given a new dimension to it. Non-violence is not mere non-killing. Non-violence is non-exploitation but exposition of the innate goodness of man. 'Gandhi takes non-violence as the law of the human race and violence as the law of the brute.' Gandhi has attached the highest importance to non-violence as ahimsa paramo dharma. For him the practice of ahimsa in the highest moral principle that one can cultivate for any kind of altruistic ideal. It is taken for granted that Ahimsa cannot be conceived without satyagraha. Satyagraha is considered as the technique of ahimsa. In order to resist social injustice and tyranny without any kind of violence, the method suggested by Gandhi is satyagraha. The term literally stands for 'clinging for truth' or 'deep love for truth'. Gandhi considers that resisting evil through evil or violence will give rise to never-ending series of miseries. That is why he has thought of 
RJPSSs, Vol. XLVI No.1, June 2020 ISSN: (P)0048-7325 (e) 2454-7026 Impact Factor 7.821 (SJIF) https://doi.org/10.31995/rjpsss.2020v46i01.13

utilizing the love-force which can counter in a better manner. It is considered as a method of conversion rather than coercion. Its purpose is to bring change in the heart of 'wrongdoers' only not enemies or opponents. This is how satyagraha is based on love and respect. These factors can help in the establishment of an ideal social order.

\section{Scientific socialism of Marx}

With the fundamental assumption that the capitalist system to be the root cause of suffering the basic intention behind the doctrine was there should be "a central authority or socio-economic center will control the production of communities as well as the distribution. By doing this the authority will safeguard the interests of the society as a whole. The state control over production and distribution is to be achieved step by step and not by forcible measures." ${ }^{2}$ Marx's economic interpretation of history proposes that since society has evolved in the dialectical process ultimately it is the economic factors like production distribution, exchange, etc. determine the cultural, intellectual, ideological, and political phenomena of the society. The ultimate goal of scientific socialism is to set up an exploitation free, classless, stateless, and egalitarian socialistic society. In his framework of thought, the basic important factors are bloodshed revolution, class-war, withering away the state, abolition of private property, dictatorship of the proletariat, etc.

Bloodshed revolution' in the words of Marx 'is the midwife of communism'.

With a view to establishing a classless and stateless society, Marx adopted a violent revolutionary method. Marxist theory of the proletarian revolution or the dictatorship of the proletariat is based on the idea that the have-not can eliminate capitalists through violent revolution against them. The theory of class struggle as advocated by Marx believes in perpetual conflict and antagonism between haves and have-nots in every stage of history. For Marx, the conflict between two opposite classes is not only inevitable but also desirable. The state according to Marx represents a class institution. It is neither natural nor necessary. It is an instrument on the basis of which the capitalists exploit the proletariats. In his own words, 'the state is the executive committee of the bourgeoisie'. The capitalistic state will be replaced by the phase of the dictatorship of the proletariat. This is the interim phase of communism. The state will be under the control of the proletariat in this phase. In this way, capitalistic elements will be eliminated by the proletariat through the institution of the state. But with the establishment of a classless society state will gradually wither away or vanish.

Marx considered capitalists as the enemy of the poor masses. Equality is possible only through the abolition of private property and the elimination of capitalist 
IDEAL SOCIAL ORDER: WHY GANDHI, NOT MARX?

Krishna Satapathy

through revolution. Marxian communism which is based on the principles of monotony, regimentation, the dictatorship of the proletariat, class war, the supremacy of the single party, and violence is the very antithesis of democracy. The communist regime is undoubtedly dictatorial.

Comparative account:

The fundamental difference between Gandhi and Marx is in their methods. Karl Marx and Marxist thinkers have glorified violence and preferred the revolutionary method. As opposed to the method of violence Gandhi adopted the method of nonviolence i.e. awakening the consciousness of good-sense. For him, the prince cannot be made equal with the peasant by cutting the head of the king. The Sarvodaya society conceived by Gandhi is based on the principle of mutual love co-operation, understanding, and goodwill. On the contrary, according to Marx the perpetual conflict and antagonism between haves and have-nots will bring class struggle and the selfish nature of man will never allow a man to remain oppressed for an indefinite period. The class-struggle is inevitable as well as desirable.

Gandhi has thought that moral pressure would be effective whereas Marx has thought that the method of revolution would be effective. Though the goal was common to destroy capitalism but the means suggested are different conspicuously. Gandhi attached importance on non-violence, chastity, non-accumulation, non-stealing, etc... which are the moral norms. Gandhi seems to have been influenced by Upanisads, Bhagavat Gita, Buddhism, and Tolstoy for his ethical and idealistic philosophy of Sarvodaya. Marx seems to have been inspired by Democritus, Epicurus, Hobbes for his materialism, and Hegel for his dialectical method to reach at scientific socialism.

\section{Epilogue}

Gandhi's social order is solely based on certain ethical preoccupations. One can very well find that his social order does ultimately pronounce some fundamental values which unfold its ethical basis. If anything is significant in Gandhi's sociopolitical philosophy, it is not mere ethical leanings rather it is the ethical foundation itself. His emphasis on equality and freedom, following non-violence as the sole means for achieving the end, to apply truth-force in place of physical force, the emphasis on equitable economic order, above all the consideration that everyone should earn his own bread, etc., have purely to establish peace in the society. In his opinion: "only truthful, non-violent and pure-hearted socialists will be able to establish a socialistic society in India and the world. To my knowledge there is no country in the world which is purely socialistic without the means described above, the existence 
RJPSSs, Vol. XLVI No.1, June 2020 ISSN: (P)0048-7325 (e) 2454-7026 Impact Factor 7.821 (SJIF) https://doi.org/10.31995/rjpsss.2020v46i01.13

of such a society is impossible". ${ }^{3}$ Here the emphasis on ethical values is quite clear. He has also said: "I do not want to rise on the ashes of the blind and deaf and the dumb. In their socialism probably there has no peace. Their one aim is material progress. For instance, America aims at having a car for every citizen which I do not. I want freedom for the full expression of my personality."4

Marx's proposal cannot be thought of without violence. But violence can never lead to peace. Rather violence will invite counter-violence. If peaceful living is the goal of socialism, the method of violence has to be rejected. It is very important to note that almost all the social problems are really moral problems because the attempt to solve a social problem becomes very easy only when the ethics behind the issue is properly taken care of. Imposition of power or force may suppress the issue for a temporary period but it cannot rule out the possibility of reoccurrence until and unless there is the change in the mind. The sarvodayadoctrine of Gandhi is an attempt to bridge the gap between theoretical ideas and practice. The emphasis on ethical considerations prompts to choose the Gandhian doctrine in lieu of Marxian.

\section{References}

1. Gandhi, M.K., Quoted from StudiesinGandhism, (Bose, N.K.,) p.67

2. Das, P.G.., History of Political Thoughts, New Central Book Agency (P) Ltd., 2002, p.653.

3. Gandhi, M.K., Harijan, 13-7-1947. p.232

4 Gandhi, M.K., Economic and Industrial Life and Relation, Complied Kher, V.B, p.45 